\title{
EVALUASI WEBSITE PEMKO PEKANBARU MENGGUNAKAN METODE HEURISTIC EVALUATION
}

\author{
${ }^{1}$ Nurmaini Dalimunthe, ${ }^{2}$ Faris Nazari, ${ }^{3}$ Khairunsyah Purba, ${ }^{4}$ Arabiatul Adawiyah \\ ${ }^{1,2,4}$ Program Studi Sistem Informasi Fakultas Sains dan Teknologi \\ ${ }^{3}$ Progam Studi Administrasi Negara Fakultas Ekonomi dan Ilmu Sosial \\ Universitas Islam Negeri Sultan Syarif Kasim Riau \\ Jalan HR. Soebrantas KM 15 No. 155 Pekanbaru - Riau \\ Email: ${ }^{1}$ nurmaini.dalimunthe@gmail.com, ${ }^{2}$ farisnazari20@gmail.com, ${ }^{3}$ khairunsyah@uin-suska.ac.id, \\ 4adawiyaharabiatul@gmail.com
}

\begin{abstract}
ABSTRAK
Kota Pekanbaru merupakan salah satu Kota di Provinsi Riau dan telah menggunakan website sebagai tempat untuk mendapatkan informasi. Tujuan dibangunya website ini ialah untuk memudahkan pengguna dalam mengakses informasi seputa Kota Pekanbaru. Dalam penerapan website ini masih terdapat beberapa permasalahan yaitu informasi yang kurang update dan lengkap serta tidak adanya menu untuk membalas kritik atau saran dari masyarakat, sehingga dapat mempengaruhi kualitas dari website tesebut. Tujuan penelitian ini adalah untuk mengevaluasi dan mengukur tingkat keberhasilan website Pemko Pekanbaru menggunakan metode heuristic evaluation dan untuk memberikan rekomendasi kepada pihak Pemko Pekanbaru agar dapat dijadikan solusi untuk meningkatkan kepuasan pengguna berdasarkan tingkat keberhasilan website. Pengambilan data melalui observasi, wawancara, dan kuesioner. Teknik pengambilan sampel menggunakan teknik Slovin dan Simple Random Sampling. Untuk metode analisis data menggunakan usability testing serta alat pengolahan data menggunakan IMB Software Statistical Product Solution (SPSS) Statistics 23. Berdasarkan hasil penelitian terhadap data yang diperoleh dari Pemko Pekanbaru, maka dapat disimpulkan bahwa didapatkan nilai persentase dari Usability Testing total ditemukan mendapatkan nilai $63,18 \%$ yang berarti menunjukkan bahwa website cukup baik bagi penggunanya, untuk total tidak ditemukan mendapatkan nilai $36,81 \%$ yang berarti menunjukkan bahwa website kurang baik bagi penggunanya.
\end{abstract}

Kata kunci: Heuristic Evaluation, Pemko Pekanbaru, Usability Testing, website.

\section{A. PENDAHULUAN}

Pemerintahan berbasis elektronik atau dikenal dengan e-government menjadi populer seiring perkembangan dan kemajuan teknologi, informasi dan komunikasi. Intruksi Presiden No 3 tahun 2003 tentang kebijakan dan startegi nasional pengembangan e-government merupakan "angin segar" bagi penerapan teknologi komunikasi dan informasi dalam proses pemerintahan yang diyakini akan meningkatkan efisiensi, efektifitas, transparansi serta akuntabilitas penyelenggaraan pemerintahan [1]. Electronic government sebagai implementasi penggunaan teknologi informasi dan komunikasi dalam pemerintahan harus disikapi sebagai peluang dan tantangan yang perlu diantisipasi dengan jalan menyiapkan perangkat dan sistem jaringan teknologi informasi yang dapat dengan mudah diakses dan dimanfaatkan bagi kesejahteraan masyarakat [2].

Pemerintah Kota Pekanbaru merupakan salah satu pemerintahan kabupaten/kota di Indonesia yang telah menerapkan electronic government didalam menjalankan urusan pemerintahannya demi terwujudnya tata kelola pemerintahan yang baik. Pembangunan $e$-gov di Kota Pekanbaru dimulai pada tahun 2009 dan mulai efektif sejak tahun 2011 di bawah pengelolaan bagian Pengelolaan Data Elektronik (PDE) Sekretariat pemerintah Kota Pekanbaru, sebagai unsur yang bertanggung jawab di dalam pembangunan dan pengembangan electronic government di Kota Pekanbaru. Di tahun anggaran 2011 pembangunan dan pengembangan electronic government mulai berjalan sebagai pelaksanaan dari Undang-undang No.11 Tahun 2008 tentang informasi dan transaksi elektronik. Peran Pemerintah Kota Pekanbaru sebagai badan publik yang menyediakan, memberikan, dan menerbitkan informasi publik diharapkan dapat berjalan maksimal dengan dibangunnya website resmi pemerintah www.pekanbaru.go.id. Perkembangan Kota Pekanbaru menuju kota metropolitan tentu juga berdampak pada perkembangan masyarakat Kota Pekanbaru yang semakin kritis. Selain itu kewajiban untuk mewujudkan sistem pemerintahan yang baik (Good Governance) mewajibkan Pemerintah Kota Pekanbaru untuk merubah perilaku dan mampu memilih media komunikasi yang mengakomodir semua yaitu dengan menggunakan internet berupa website pemerintah dengan domain www.pekanbaru.go.id.

Pengaplikasian website pemerintah Kota Pekanbaru merupakan perwujudan dari kebijakan 
pemerintah untuk menerapkan transparansi atau keterbukaan disemua tingkat struktur birokrasi pemerintah sehingga semua pihak dapat dengan jelas mengetahui apa yang sedang direncanakan dan dilaksanakan oleh pemerintah. Sebagaimana tertuang dalam Instruksi Presiden No 3 tahun 2003 tentang kebijakan dan strategi pengembangan $e$ Government dan merupakan salah satu cara dalam meningkatkan layanan informasi publik. Sehingga jelas bahwa posisi website bagi pemerintah daerah sebagai salah satu sarana startegi dalam menjalankan aktivitas pemerintah [3]

Salah satu fasilitas internet yang paling populer adalah world wide web,yakni sistem yang membuat informasi dapat diakses melalui pendekatan hiperteks [4]. Website merupakan situs web atau lokasi maya pada web yang memiliki alamat internet tersendiri [5]. Sebuah website bisa berupa hasil kerja dari perorangan atau individu, atau menunjukkan kepemilikan dari sebuah organisasi, perusahaan, dan biasanya website itu menunjukkan beberapa topik khusus atau kepentingan tertentu. Sebuah website bisa berisi hyperlink yang bisa menghubungkan ke website lain, jadi kadangkala perbedaan antara website yang dibuat oleh individu perseorangan dengan website yang dibuat oleh organisasi bisnis bisa saja tidak kentara. Halaman web dapat dilihat atau diakses melalui jaringan komputer dan internet, perangkatnya bisa saja berupa komputer pribadi, laptop, PDA, ataupun telepon seluler [6].

Salah satu poin penting dalam membangun aplikasi berbasis web adalah berkaitan dengan perancangan desain antar muka. Aplikasi yang akan dibangun harus memiliki tampilan antar muka yang user-friendly. Pembuatan suatu sistem informasi harus dilakukan dengan memperhatikan faktor kemudahan penggunaan (usability).

Heuristic evaluation adalah suatu cara pemeriksaan usability untuk perangkat lunak komputer yang membantu mengenali masalahmasalah usability pada rancangan antarmuka [7]. Heuristic evaluation juga merupakan salah satu metode yang paling banyak digunakan untuk mengukur tingkat kenyamanan pengguna dalam hal interaksi manusia dan komputer (IMK). Tujuan utama Heuristic Evaluation adalah untuk mengidentifikasi masalah yang berkaitan dengan rancangan antarmuka. Metode Heuristic Evaluation menggunakan 10 prinsip dalam mengevaluasi pada tingkat usability yang dijadikan acuan untuk menentukan keputusan yang sudah diambil oleh pengguna.

Namun permasalahan yang ada yaitu belum pernah dilakukan evaluasi dengan metode heuristic evaluation dan dalam penerapannya masih terdapat permasalahan yaitu informasi yang kurang update dan lengkap serta tidak adanya menu untuk membalas kritik atau saran dari masyarakat, sehingga dapat mempengaruhi kualitas dari website tersebut. Hal ini dirasa perlu untuk website Pemko Pekanbaru, website ini merupakan upaya pemko untuk menerapkan e-government.

Penelitian tentang evaluasi website dengan metode Heuristic Evaluation pernah dilakukan oleh peneliti-peneliti sebelumnya, seperti: (Ni Putu Linda Santiari dan I gede Surya Rahayuda, 2017 ; Putu Krisnayani $d k k$., 2016 ; Amir Ali $d k k$., 2016 Nabila Oper $d k k ., 2017)$.

Sudah banyak penelitian yang menunjukkan bahwa evaluasi pada website sangat dibutuhkan untuk meningkatkan pelayanan website, diantaranya penelitian oleh [8], mengungkapkan bahwa yang menjadi latar belakang permasalahannya adalah website yang belum pernah diukur kualitasnya pada implementasinya dari peraturan e-Governmnet telah dilakukan didapatkan oleh Pemerintah Kabupaten Ogan Ilir. Dari penelitian yang dilakukan didapatkan sebuah kesimpulan dari hasil penguji bahwa website pemerintah daerah Ogan Ilir dikatakan cukup bagus.

Berdasarkan permasalahan diatas perlu dilakukan evaluasi untuk melihat sejauh mana kualitas website telah berfungsi dengan baik sesuai kepuasan pengguna, maka dilakukan penelitian yang berjudul "Evaluasi Website Pemko Pekanbaru Menggunakan Metode Heuristic Evaluation”.

\section{B. LANDASAN TEORI}

\section{B.1. Website}

Website merupakan salah satu sumber daya internet yang berkembang pesat. Website disebut juga site, situs, situs web atau portal. Merupakan kumpulan halaman web yang berhubungan antara satu dengan lainnya, halaman pertama sebuah website adalah home page, sedangkan halaman demi halamannya secara mandiri disebut web page, dengan kata lain website adalah situs yang dapat diakses dan dilihat oleh para pengguna internet diseluruh dunia [9].

\section{B.2. Kualitas Informasi Website}

Kualitas informasi mengukur kualitas keluaran dari sistem informasi. Mengembangkan enam item pertanyaan untuk mengukur kepentingan persepsi dan kebergunaan informasi dari informasi yang disajikan dan laporan-laporan yang dihasilkan oleh sistem informasi tersebut. Indikator yang diukur meliputi [10]:

1) Kelengkapan (completeness).

2) Ketepatan (precission).

3) Akurasi (accuracy).

4) Keandalan (reliability).

5) Kekinian (currency).

6) Bentuk Keluaran (format of output).

\section{B.3. Fungsi Website}

Secara umum web mempunyai fungsi sebagai berikut [11]:

1. Fungsi Komunikasi 
Situs web yang mempunyai fungsi komunikasi pada umumnya adalah situs web dinamis. Karena dibuat menggunakan pemograman web (server side) maka dilengkapi fasilitas yang memberikan fungsifungsi komunikasi, seperti webmail, form contact, chatting form, dan yang lainnya.

2. Fungsi Informasi

Situs web yang memiliki fungsi informasi pada umumnya lebih menekankan pada kualitas bagian kontennya, karena tujuan situs tersebut adalah menyampaikan isinya.

\section{Fungsi Entertainment}

Situs web juga dapat memiliki fungsi entertainment atau hiburan. Bila situs web kita berfungsi sebagai sarana hiburan maka penggunaan animasi gambar dan elemen bergerak dapat meningkatkan mutu presentasi desainnya, meski tetap harus mempertimbangkan kecepatan download-nya.

\section{Fungsi Transaksi}

Situs web dapat dijadikan sarana transaksi bisnis baik barang, jasa atau lainnya. Situs web ini menghubungkan perusahaan, konsumen dan komunitas tertentu melalui transaksi elektronik. Pembayarannya bisa menggunakan kartu kredit, transfer atau dengan membayar secara langsung.

\section{B.4. Evaluasi}

Evaluasi merupakan salah satu rangkaian kegiatan dalam meningkatkan kualitas, kinerja, atau produktifitas suatu lembaga dalam melaksanakan programnya. Fokus evaluasi adalah individu, yaitu prestasi belajar yang dicapai kelompok atau kelas. Melalui evaluasi akan diperoleh informasi tentang apa yang telah dicapai dan apa yang belum dicapai. Selanjutnya, informasi ini digunakan untuk perbaikan suatu program [12].

\section{B.5. Standar Evaluasi}

Standar yang dipakai untuk mengevaluasi suatu kegiatan tertentu dapat dilihat dari tiga aspek utama, yaitu [12]:

1. Utility (manfaat)

Hasil evaluasi hendaknya bermanfaat bagi manajemen untuk pengambilan keputusan atas program yang sedang berjalan.

2. Accuracy (akurat)

Informasi atas hasil evaluasi hendaklah memiliki tingkat ketepatan tinggi.

3. Feasibility (layak)

Hendaknya proses evaluasi yang dirancang B.6. Usability

dapat dilaksanakan secara layak.

Usability berasal dari kata usable yang secara umum berarti dapat digunakan dengan baik. Sesuatu dapat dikatakan berguna dengan baik apabila kegagalan dalam penggunaannya dapat dihilangkan atau diminimalkan serta memberikan manfaat dan kepuasan bagi pengguna. Ketika sebuah produk atau jasa benar-benar dapat dipergunakan dengan baik, pengguna dapat melakukan apa yang dia inginkan dengan cara yang diharapkan serta mampu untuk melakukannya tanpa halangan, keraguan, atau pertanyaan [13].

Menurut Jakob Nielsen, Secara umum cara mengukur dan menilai usability sebuah situs bersifa $\mathrm{t}$ relative dan bergantung pada bagaimana penggun a dapat menyelesaikan sekumpulan task, terdapat komponen-komponen yang dapat dijadikan patokan dalam mengukur usability, yakni:

a. Learnability, mudah untuk di pelajari. Dengan meletakkan isi yang paling penting pada bagian atas halaman agar pengunjung dalam menemukannya dengan cepat.

b. Efficiency, tingkat kecepatan pengguna. Dengan menyediakan link seperlunya saja agar mengunjung dapat mencapai informasi yang di perlukan dengan cepat dan mudah.

c. Memorability, mudah untuk di ingat. Dengan tidak banyak melakukan perubahan yang mencolok pada situs, khususnya pada navigasi.

d. Eror, tingkat kesahalan rendah. Dengan menghindari link yang tidak berfungsi (brokenlink) atau halaman masih dalam proses pembuatan (under construction).

e. Satisfaction, kepuasan pengguna. Hal ini wajib di perhatikan karena berhubungan dengan kelangsungan situs web. Oleh karena itu sebuah website seharusnya mudah di gunakan oleh user.

\section{B.7. Heuristic Evaluation}

Heuristic Evaluation adalah sistem evaluasi untuk software komputer berbasis pengguna. Sistem ini melibatkan evaluator untuk memberikan masukan yang kemudian dikategorikan dalam prinsip-prinsip heuristik. Pendekatan yang diciptakan Nielsen di tahun 1990, adalah cara mengevaluasi yang cukup terpercaya dalam dunia saat ini. Evaluasi Heuristik adalah panduan, prinsip umum, atau aturan yang dapat menuntun keputusan rancangan atau digunakan untuk mengkritik suatu keputusan yang sudah diambil [13].

Heuristic Evaluation diusulkan oleh Nielsen dan Molich, Pada pendekatan ini, sekumpulan kriteria usability atau heuristic diidentifikasi dan perancangan dilaksanakan misalnya dimana kriteria dilanggar. Tujuan dari evaluasi heuristik adalah untuk memperbaiki perancangan secara efektif. Terdapat 10 prinsip umum Jakob Nielsen untuk desain interaksi, yaitu:

1. Visibility Of System Status, tampilan informasi dari status sitem. Sistem harus selalu memberi tahu pengguna tentang apa yang sedang terjadi, melalui umpan balik yang sesuai dalam waktu yang wajar.

2. Match between system and the real world, Cocok antara sistem dan dunia nyata. Sistem harus berbicara bahasa pengguna, dengan katakata, ungkapan dan konsep yang akrab bagi pengguna, bukan istilah yang berorientasi pada 
sistem. Ikuti konvensi dunia nyata, membuat informasi muncul dalam urutan alami dan logis.

3. User control and freedom, Kontrol pengguna dan kebebasan. Pengguna sering memilih fungsi sistem karena kesalahan dan memerlukan "pintu keluar darurat" yang ditandai dengan jelas untuk meninggalkan keadaan yang tidak diinginkan tanpa harus melalui dialog yang diperluas. (Dukungan undo dan redo).

4. Consistency and standards, Konsistensi apakah kata-kata, situasi, atau tindakan yang berbeda berarti hal yang sama.

5. Error prevention, Kesalahan pencegahan. Bahkan lebih baik daripada pesan kesalahan yang baik adalah desain yang hati-hati sehingga mencegah terjadinya masalah. Entah menghilangkan kondisi rawan kesalahan atau memeriksa mereka dan memberi pengguna opsi konfirmasi sebelum mereka melakukan tindakan tersebut.

6. Recognition rather than recall, Pengakuan bukan recall. Minimalkan beban memori pengguna dengan membuat objek, tindakan, dan pilihan terlihat. Pengguna seharusnya tidak perlu mengingat informasi dari satu bagian dialog yang lain. Petunjuk penggunaan sistem harus terlihat atau mudah dicerna kapanpun.

7. Flexibility and efficiency of use, Fleksibilitas dan efisiensi penggunaan. Akselerator - yang tidak terlihat oleh pengguna pemula - mungkin sering mempercepat interaksi bagi pengguna ahli sehingga sistem dapat memenuhi pengguna berpengalaman dan izinkan pengguna menyesuaikan tindakan yang sering dilakukan.

8. Aesthetic and minimalist design, Desain estetika dan minimalis. Dialog seharusnya tidak berisi informasi yang tidak relevan atau jarang dibutuhkan. Setiap unit tambahan informasi dalam sebuah dialog bersaing dengan unit informasi yang relevan dan mengurangi visibilitas relatif mereka.

9. Help users recognize, diagnose, and recover from errors, Bantu pengguna mengenali, mendiagnosis, dan memulihkan dari kesalahan. Pesan kesalahan harus dinyatakan dalam bahasa sederhana (tanpa kode), justru menunjukkan masalahnya, dan secara konstruktif menyarankan sebuah solusi. dan standar. Pengguna tidak perlu bertanyatanya

10. Help and documentation, Bantuan dan dokumentasi. Meskipun lebih baik jika sistem dapat digunakan tanpa dokumentasi, mungkin perlu memberikan bantuan dan dokumentasi. Setiap informasi semacam itu harus mudah dicari, terfokus pada tugas pengguna, daftar langkah konkret yang harus dilakukan, dan jangan terlalu besar.

\section{B.8. Uji Validitas dan Reliabilitas}

Uji validitas atau kebenaran adalah suatu indeks yang menunjukkan alat ukur tersebut benar-benar mengukur apa yang diukur, validitas ini menyangkut akurasi instrument. Untuk mengetahui apakah kuisioner yang disusun tersebut valid, maka perlu dengan uji korelasi antar skor (nilai) tiap-tiap butir pernyataan dengan skor total kuesioner tersebut. Kriteria dalam pengujian hipotesis validitas dalam penelitian adalah:

1. Kuesioner dikatakan valid apabila $\mathrm{R}$ hitung > $\mathrm{R}$ tabel.

2. Kuesioner dinyatakan tidak valid apabila $R$ hitung $\leq \mathrm{R}$ tabel.

Uji reliabilitas adalah indeks yang menunjukkan sejauh mana suatu alat pengukur dapat dipercaya atau dapat diandalkan. Reliabilitas menunjukkan kemantapan atau konsistensi hasil pengukuran. Suatu alat pengukuran dikatakan mantap atau konsisten, apabila untuk mengukur sesuatu berulang kali, alat pengukur itu menunjukkan hasil yang sama dalam kondisi yang sama. Butir pernyataan dikatakan reliable atau handal apabila jawaban seseorang terhadap pernyataan adalah konsisten.

\section{B.9. Usability Testing}

Uji ketergunaan adalah mengukur efisiensi, kemudahan dipelajari, dan kemampuan untuk mengingat bagaimana berinteraksi tanpa kesulitan atau kesalahan, uji ketergunaan ini merupakan attribut untuk menilai seberapa mudah interface website digunakan [14]. Langkah-langkah dalam melakukan uji ketergunaan adalah:

1. Memilih Objek, langkah ini adalah proses penentuan objek yang akan diteliti.

2. Memilih responden untuk pengisian kuisioner berdasarkan sampel yang sudah di tentukan.

3. Mempresentasikan tugas kepada responden, langkah ini adalah memberikan penjelasan kepada responden bahwa yang di uji bukan responden tetapi objek penelitian.

4. Memberikan tugas kepada responden, yaitu memberikan tugas-tugas dalam kuisioner untuk di jawab oleh responden.

5. Pengisian kuisioner dari responden, responden memberikan jawaban untuk kuisioner yang diberikan sesuai dengan yang di alami oleh responden.

6. Analisa jawaban dari responden terhadap website dari segi jawaban responden.

7. Dari evaluasi yang dilakukan akan mendapatkan informasi yang lengkap mengenai kelebihan dan kekurangan website.

8. Dari hasil evaluasi memberikan rekomendasi.

\section{METODOLOGI PENELITIAN}




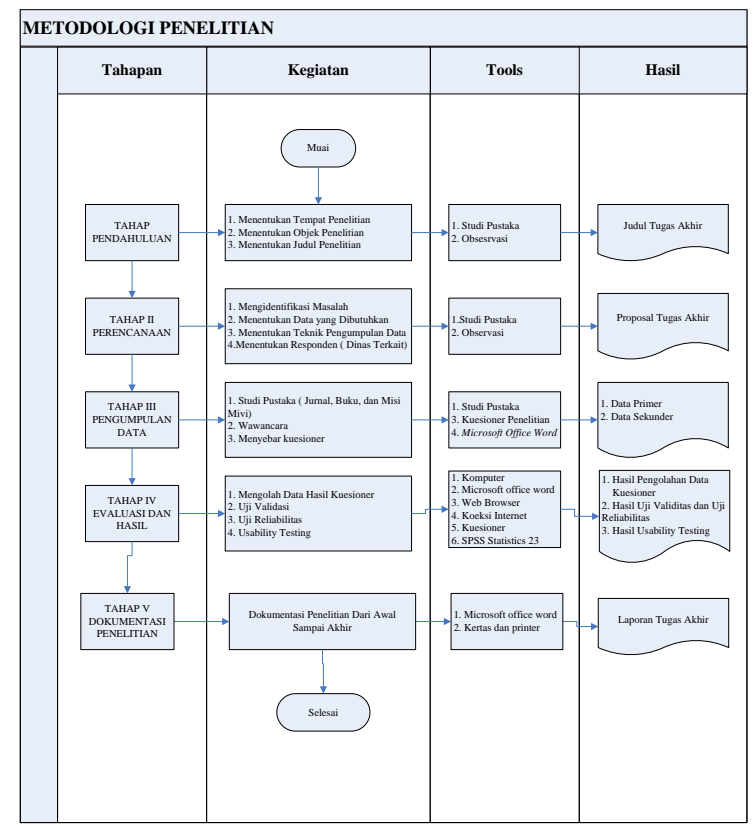

\section{ANALISA DAN PEMBAHASAN}

Pada bab ini menjelaskan tentang analisis dan pengukuran tingkat keberhasilan website. Pemko Pekanbaru dari segi usability menggunakan metode Heuristic Evaluation. Tahapan pengukuran dilakukan dengan observasi dan wawancara untuk mengetahui kondisi website yang sedang berjalan. Kemudian menyebarkan kuesioner untuk menentukan nilai pengaruh kualitas penggunaan (usability) setelah data diperoleh kemudian diolah dan dianalisis sehingga dapat diketahui bagaimana pengaruh keberhasilan penerapan website dilihat dari tingkat usability terhadap 10 prinsip Heuristic Evaluation tersebut sehingga dapat menghasilkan rekomendasi dan saran.

Prinsip-prinsip Heuristic Evaluation yang digunakan pada penelitian ini sebanyak 10 prinsip yaitu visibility of system status, match between system and real world, user control and freedom, consistency and standars, error prevention, recognition rather than recall, flexibility and efficiency of use, aesthetic and minimalist design, help user recognize, and recover from error, dan help and documentation. Kemudian masing-masing prinsip tersebut diberi kode H1 sampai dengan kode H10 yang merupakan singkatan dari Heuristic 1 sampai 10 .

\section{E. PEMBAHASAN}

Berdasarkan hasil analisis statistik penelitian yang dilakukan mengenai pengukuran tingkat keberhasilan website dari segi usability pada website Pemko Pekanbaru maka didapatkan penjelasan hasil analisis sebagai berikut:

\section{E.1. Hasil Uji Validitas}

Pengujian dilakukan dengan cara membandingkan nilai korelasi product moment atau $\mathrm{R}$ tabel dengan $\mathrm{R}$ hitung, dimana $\mathrm{R}$ hitung harus lebih besar dari $\mathrm{R}$ tabel. Di dalam $\mathrm{R}$ tabel product moment untuk jumlah 100 responden dengan taraf signifikan $10 \%$ adalah 0,163 .

Berdasarkan hasil pengolahan data validitas, dapat diketahui bahwa pengolahan data yang didapatkan pada setiap item pernyataan adalah valid sesuai dengan pengukuran validitas, nilai korelasi lebih besar dari R tabel.

\section{E.2. Hasil Uji Reliabilitas}

Uji reliabilitas dengan nilai alpha 0.60, berdasarkan hasil uji reliabilitas yang dilakukan terhadap 16 pernyataan, semua pertanyaan yang dinyatakan sangat reliable karena seluruh pernyataan mendapat nilai Cronbach alpha 0.976 lebih besar dari nilai alpha.

\section{E.3. Hasil Uji Usability Testing}

Berdasarkan hasil usability testing menggunakan metode Heuristic Evaluation berhasil menemukan beberapa variabel persentase terendah yaitu variabel H3 P5 61\% yang berarti cukup baik untuk usability website, variabel H5 P8 58\% yang berarti cukup baik untuk usability website, variabel H7 P10 31\% yang berarti kurang baik untuk usability website, variabel H7 P11 38\% yang berarti kurang baik untuk usability website, variabel H8 P12 31\% yang berarti kurang baik untuk usability website, variabel H8 P13 38\% yang berarti kurang baik untuk usability website, variabel H9 P14 59\% yang berarti cukup baik untuk usability website, variabel H9 P15 $60 \%$ yang berarti cukup baik untuk usability website, variabel H10 P16 69\% yang berarti baik untuk usability website.

\section{E.4. Hasil Akhir}

Setelah didapatkan nilai persentase dari hasil total ditemukan dan total tidak ditemukan mendapatkan nilai $63,18 \%$ untuk hasil total ditemukan yang berarti menunjukkan bahwa website Pemko Pekanbaru cukup baik bagi penggunanya. Untuk total nilai tidak ditemukan mendapatkan nilai $36,81 \%$ yang berarti menunjukkan bahwa website Pemko Pekanbaru kurang baik bagi penggunanya.

\section{F. KESIMPULAN}

Berdasarkan hasil evaluasi yang telah di lakukan terhadap website Pemko Pekanbaru menggunakan metode Heurustic Evaluation, maka dapat diambil kesimpulan bahwa:

1. Evaluasi tingkat keberhasilan website dari segi usability menggunakan metode Heuristic Evaluation berhasil menemukan beberapa variabel dari metode Heuristic Evaluation yang mendapatkan persentase terendah dan harus segera di lakukan perbaikan secara cepat agar berhasilnya tingkat usability pada website Pemko Pekanbaru. Dari hasil perhitungan masalah usability tersebut, persentase terrendah adalah pada variabel H3 P5 61\%, variabel H5 P8 58\%, variabel H7 P10 31\%, variabel H7 P11 38\%, variabel H8 P12 31\%, variabel H8 
P13 38\%, variabel H9 P14 59\%, variabel H9 P15 60\%, variabel H10 P16 69\%. Hal ini sebaiknya dilakukan perbaikan secara cepat terhadap website sesuai dengan solusi yang direkomendasikan.

2. Berdasarkan pada 10 prinsip Heuristic Evaluation yang mempengaruhi keberhasilan penerapan website pada tingkat usability yaitu di dapatkan hasil rekomendasi sebagai solusi ialah rekomendasi yang dapat diberikan adalah perlu adanya menu untuk pilihan font (type,size) pada website sehingga dapat membuat pengunjung betah dan perlu adanya design website yang menarik dan sebaiknya pihak pengelola website memberikan menu search (pencarian) pada website agar dapat memberikan kemudahan untuk pengguna dan bisa tercapainya tujuan yang dibutuhkan, serta menambah fasilitas keterangan "contact us" untuk korespondensi seperti memberikan alamat email yang bisa digunakan untuk keperluan yang dibutuhkan pengguna.

\section{REFERENSI}

[1] Yohana, Nova, dkk. "Pemanfaatan Website Pemerintah Kota Pekanbaru Dalam Mewujudkan Good Governance”. Jurnal Mayarakat Telematika dan Informasi Vol. 5 No. 2 November 2014 Hal: 153-168. 2014.

[2] Anggrahini, M. D., Rochayanti, C., dan Sosiawan, E. A. (2008). Peran Humas Pemerintah Kabupaten Sragen dalam Pengelolaan ISI Informasi Website PEMDA Sebagai Media Communications Relations dengan Masyarakat. Jurnal Ilmu Komunikasi, Volume 6, Nomor 2, 145-151.

[3] Masyhur, Firdaus. 2014. Kinerja Website Resmi Pemerintah Provinsi di Indonesia Official Website Performance Local Government in Indonesia. Jurnal Pekomnas Volume 17 Nomor 1. Dari Balai Besar Pengkajian dan Pengembangan Komunikasi dan Informatika (BBPPKI) Makassar.

[4] Suyanto, Asep Herman. “Web Design Theory and Practices”. Andi,Yogyakarta. 2007.

[5] Sahid. (2006). Teknologi Informasi dan Komunikasi. Bandung : Yudhistira.

[6] Dipanegara, Arya. (2011). Langsung jago bikin website. Jakarta: PT. Niaga Swadaya.

[7] Nielsen, Jakob, Robert L Mack. 1994. Usability Inspection Methods. New York : John Wiley and Son.
[8] Candra, Irawan. "Evaluasi Kualitas Website Pemerintah Daerah Dengan Menggunakan Webqual”. Ogan Ilir. 2011.

[9] Kadir, Abdul dkk. "Dasar Pemograman Web Perpustakaan”. Jurnal Teknologi Informasi 2011.

[10] Delone, William H. dan Ephraim R. Mclean. (2003). The Delone and Mclean Model of Information System Success: A Ten-Year Update. Journal of Management Information Systems / Spring 2003.

[11] Maslan, Andi. "Pengukuran Kualitas Layanan Website Pemerintah Kota Batam Menggunakan Webqual 4.0". Jurnal Ilmiah Informatika, Vol 1, No. 3, ISSN: 2337-8379, 2014.

[12] Sari, Kamala Dewi. "Evaluasi Pemanfaatan Situs Chem-Is-Try.Org dalam Pemenuhan Kebutuhan Informasi Oleh Mahasiswa Departemen Kimia Fakultas Matematika dan Ilmu Pengetahuan Alam (FMIPA) USU'.Tesis Fakultas Sastra. Tidak diterbitkan”. Medan. 2010

[13] Krisnayani, Putu, dkk "Analisa Usability Pada Website UNDIKSHA Dengan Menggunakan Metode Heuristic Evaluation". Kumpulan Artikel Mahasiswa Pendidikan Teknik Informatika (KARMAPATI) Volume 5 Nomor 2, 2016.

[14] Hidayat, Wahyu, dkk "Penerapan Metode Usability Testing Pada Evaluasi Situs Web Pemerintahan Kota Prabumulih". Jurnal Teknik Informatika Universitas Bina Darma Palembang, 2014. 